\title{
METABOLIC PROFILE OF COWS BLOOD AFTER TREATMENT THE FOLLICULAR CYSTS IN DIFFERENT WAYS
}

\author{
S. B. Kornyat \\ s_kornyat@inenbiol.com.ua
}

Institute the Animal Biology NAAS,

38 Vasyl Stus str., Lviv 79034, Ukraine

The aim of the study was to determine some biochemical parameters in the blood of cows (Ukrainian black and white dairy breed) with follicular ovarian cyst at the $1^{\text {st }}$ or $2^{\text {nd }}$ lactation after the application of different methods of treatment and comparative analysis of these treatment regimens. In the treatment of cows of control group the intramuscular injection of Surfagon was used at doses of 10,10 and $5 \mathrm{ml}$ respectively on the $1^{\text {st }}, 3^{\text {rd }}$ and $5^{\text {th }}$ days of treatment. For treatment of cows of experimental group the intramuscular injection of liposomal emulsion with inclusion of extracts of herbs (wild thyme (Thymusserpyllum L.), common yarrow (Achilleamillefolium), common nettle (Urticadioica L.)) combining with synthetic gonadotropin releasing hormone was applied twice with interval of 3 days.

It has been found that on $7^{\text {th }}$ day after treatment of cows with follicular cysts progesterone level increased in the blood serum of animals in control and experimental groups comparing to the indicators before treatment and on the $3^{\text {rd }}$ day of treatment in both groups. The progesterone level in the blood of cows in experimental group was higher by $33.64 \%$ than in control $(P<0.01)$. This may indicate the revitalization of the ovary functioning as a result of treatment that was more effective in experimental group than in control. On the $7^{\text {th }}$ day of treatment of cows with follicular ovarian cyst cholesterol level was within the physiological norm in the blood serum of animals in both groups but the parameter was higher by $8.71 \%$ in the blood serum of cows in experimental group and this difference was significant $(P<0.05)$. This may indicate a greater impact of regimen of treatment of cows in experimental group on the revitalization functioning of the reproductive system and metabolism of cholesterol in the organism of animals.

Due to the research results, we consider that it is appropriate to continue studies on the use of wild thyme, common yarrow and common nettle to treat cows with ovarian follicular cyst.

Keywords: BLOOD, COWS, FOLLICULAR CYSTS, TREATMENT, PROGESTERONE, ESTRADIOL, CAROTENE, CHOLESTEROL, ASCORBIC ACID

\section{МЕТАБОЛІЧНИЙ ПРОФІЛЬ КРОВІ КОРІВ ЗА ЛІКУВАННЯ ФОЛІКУЛЯРНИХ КІСТ РІЗНИМИ СПОСОБАМИ}

\author{
С. Б. Корнят \\ s_kornyat@inenbiol.com.ua
}

Інститут біології тварин НААН,

вул. В. Стуса 38, Львів, 79034, Україна.

Метою дослідження було визначення деяких біохімічних показників крові корів украӥнської чорно-рябої молочної породи 1-2-ї лактації, хворих на фолікулярну кісту яєчника, та протягом лікування при застосуванні різних способів лікування, і порівняльний аналіз циих схем лікування. При лікуванні корів контрольної групи застосовували внутрішньом'язове введення препарату «Сурфагон» на 1-й, 3-й та 5-й дні лікування в дозах 10, 10 та 5 мл відповідно. Для лікування корів дослідної групи двічі з інтервалом 3 дні застосовували внутрішньом'язове введення ліпосомального препарату з включенням витяжок з лікарських рослин (чебречь звичайний, деревій звичайний, кропива дводомна) у поєднанні з синтетичним гонадотропін-рилізинг гормоном.

Встановлено, на 7-й день після лікування корів з фолікулярними кістами відбулося зростання рівня прогестерону в сироватиі крові корів контрольної та дослідної груп порівняно з цими показниками до лікування. На 3-й день після лікування у двох групах і в дослідній групі його рівень був на 33,64 \% більшим $(P<0,01)$, ніж у тварин контрольної групи. Це може бути свідченням активізачії роботи яєчника внаслідок лікування, більш ефективного у дослідній групі, ніж у контрольній. Рівень холестеролу на 7-й день після лікування корів з фолікулярною кістою в сироватиі крові тварин контрольної і дослід- 
ної груп був у межах фізіологічної норми, проте в дослідній групі він був більшим на 8,71\% (P<0,05), що може свідчити про більший вплив схеми лікування, яку застосовували в дослідній групі корів на активізацію роботи статевої системи та обмін холестеролу в організмі корів.

3 огляду на отримані результати, вважаємо за дочільне продовження досліджень з вивчення використання чебрецю звичайного, деревію звичайного та кропиви дводомної при лікуванні корів з фолікулярною кістою яєчника.

Ключові слова: КРОВ, КОРОВИ, ФОЛІКУЛЯРНА КІСТА, ЛІКУВАННЯ, ПРОГЕСТЕРОН, ЕСТРАДІОЛ, КАРОТИН, ХОЛЕСТЕРОЛ, АСКОРБІНОВА КИСЛОТА

\title{
МЕТАБОЛИЧЕСКИЙ ПРОФИЛЬ КРОВИ КОРОВ ПРИ ЛЕЧЕНИИ ФОЛЛИКУЛЯРНЫХ КИСТ РАЗЛИЧНЫМИ СПОСОБАМИ
}

\author{
С. Б. Корнят \\ s_kornyat@inenbiol.com.ua
}

Институт биологии животных НААН,

Ул. В. Стуса 38, Львов, 79034, Украина.

Целью исследования было определение некоторых биохимических показателей крови коров украинской черно-пестрой молочной породы 1-2-й лактачии, больных фолликулярной кистой яичника, во время лечения при применении различных способов лечения и сравнительный анализ этих схем лечения. При лечении коров контрольной группь применяли им введение препарата «Сурфагон» на 1, 3-й и 5-й дни лечения в дозах 10, 10 и 5 мл соответственно. Для лечения коров опытной группь применяли внутримышечное введение липосомального препарата с включением вытяжек из лекарственных растений (тимьян обыкновенный, тысячелистник обыкновенный, крапива двудомная) в сочетании с синтетическим гонадотропин-рилизинг гормоном два раза с интервалом 3 дня.

Установлено, что на 7-й день после лечения коров с фолликулярными кистами произошел рост уровня прогестерона в сыворотке крови коров контрольной и опытной групп по сравнению с этими показателями до начала лечения и на 3-й день после лечения в двух группах. В опытной группе уровень его был на 33,64\% больще, чем у животных контрольной группы и разница была достоверной $(P<0,01)$. Это может быть свидетельством активизации работь яичника вследствие лечения, более эффективного в опытной группе, чем в контрольной. Уровень холестерола на 7-й день после лечения коров с фолликулярной кистой в сыворотке крови коров контрольной и опытной групп находился в пределах физиологической нормы, однако в опытной группе он был больше на 8,71 \% (P<0,05), что может свидетельствовать о большем влиянии схемы лечения, применявшейся в опытной группе коров на активизацию работы половой системы и обмен холестерола в организме коров.

Исходя из полученных результатов, считаем иелесообразным продолжение исследований по изучению использования чабреца, тысячелистника обыкновенного и крапивы двудомной при лечении коров с фолликулярной кистой яичника.

Ключевые слова: КРОВЬ, КОРОВЫ, ФОЛЛИКУЛЯРНЫЕ КИСТЫ, ЛЕЧЕНИЕ, ПРОГЕСТЕРОН, ЭСТРАДИОЛ, КАРОТИН, ХОЛЕСТЕРОЛ, АСКОРБИНОВАЯ КИСЛОТА

Ovarian cysts are one of the main problems of reproduction in dairy cattle breeding. Follicular cysts are anovulatory follicular structures that are found in 10-13\% of dairy cows in postpartum period [1]. The first physiological cause for the formation of follicular cysts is a disorders of the work hypothalamus, which causes preovulatoric increased levels of luteinizing hormone follicular in the response to estradiol. The factor responsible for this effect can be hypothalamus progesterone. Intermediate levels of progesterone prevent ovulation and contribute to the persistence of dominant follicles in cows with undisturbed cycles. It has been found that $66 \%$ of cows with ovarian follicular cysts had intermediate progesterone concentrations $(0.1-1.0 \mathrm{ng} / \mathrm{mL})$ at the time of detection. Most follicles (76 \%) which evolved in the presence of intermediate concentrations of progesterone were cysts. Only $10 \%$ of them were ovulated [2].

Cystic degeneration of the ovaries in most cases is the cause of infertility of young, highly 
productive cows which have not yet fully implemented highbreed and productive quality. To correct reproductive function of females a number of hormones was used (PMSG, FSH, hCG, prostaglandins, etc.), the cost of which is high enough and their use can cause changes in the hormonal profile of animals. Recently, to stimulate reproductive function using herbal medicines that have the effect of gonadotropic or steroid hormones stimulate the secretion [3, 4]. Significant achievements with the use of herbal remedies are described in the medical literature. However, the results obtained in veterinary medicine are of ambiguous nature. In particular, the same herbal medicines in some cases show a positive treatment effect and in the other they have some reservations with their use. In addition, there is almost no data on the combined use of synthetic hormonal and herbal drugs. Therefore, we expected to develop the ways of regulating reproductive functions of animals under physiological and pathological conditions, especially in the reproductive organs with the use of combination therapies that can provide effective treatment based on the study of physiological, biochemical parameters of animals [5-7].

\section{Materials and methods}

The research was conducted in experimental state farm "Pasichna" (Khmelnytsky region) on cows Ukrainian black and white dairy breed of $1^{\text {st }} 2^{\text {nd }}$ lactation. Due to the collecting history of clinical disease and by rectal examination animal diagnostics of functional state among the ovaries the animals with ovarian follicular cysts were selected. Cows with the disease were divided depending on the treatment to control and experimental groups of 5 animals in each group. Groups were formed by the following treatment regimens of these pathology. Specifically:

\section{Treatment of follicular cysts.}

The control group treatment scheme:

$1^{\text {st }}$ day - intramuscular injection of Surfagon $(10 \mathrm{ml})$;

$3^{\text {rd }}$ day - intramuscular injection of Surfagon

$(10 \mathrm{ml})$;

$5^{\text {th }}$ day - intramuscular injection of Surfagon $(5 \mathrm{ml})$.

\section{Experimental group:}

intramuscular injection of liposomal emulsion with the addition of phyto-substances (wild thyme (Thymusserpyllum L.), common yarrow (Achilleamillefolium), common nettle (Urticadioica $L$.)) with gonadotropin releasing hormone twice with an interval of 3 days.

In order to clarify the processes that occur in animals during the course of diseases and their treatment blood samples of cows in experimental and control groups were taken immediately before treatment, after 3 and 7 days after treatment. In blood samples we determined the concentrations of progesterone and estradiol-17 $\beta$, carotene content, total cholesterol, ascorbic acid. For research in the blood of cows laboratory methods described in the handbook edited by Academician NAAS V. V. Vlizlo (Lviv, 2012) were used [8]. The resulting digital data was processed statistically using Microsoft Office Excel.

\section{Results and discussion}

In the analysis of biochemical parameters of blood serum of cows with ovarian follicular cysts before treatment (Table 1) was get to low progesterone and high estradiol. Between the control and experimental groups these data differ within 13.95 and $5.91 \%$ respectively, indicating approximately the same level of development of this disease in all animals selected. The level of carotene in both groups was within the physiological norm, and in the experimental group differed from the control by $2.55 \%$. The level of serum cholesterol was within the physiological norm, and in the experimental group it differed from the reference by $1.1 \%$. The content of ascorbic acid in blood serum of cows was also within the physiological norm, and the difference between the control and experimental groups of cows was insignificant.

In the analysis of progesterone levels in serum of cows in control and experimental groups on the $3^{\text {rd }}$ day after treatment of follicular cysts (Table 2) it should be noted that there was a significant increase of its level compared to the index before treatment in two groups, which may indicate the beginning of ovarian sexual cycle under the scheme. In the experimental group it was at $29.85 \%$ more than in the animals of 


\section{Indicators blood of cows in the treatment of ovarian follicular cysts before treatment $(M \pm m ; n=5)$}

\begin{tabular}{|l|c|c|}
\hline \multicolumn{1}{|c|}{ Indicator } & \multicolumn{2}{c|}{ Cows groups } \\
\cline { 2 - 3 } & Control & Experimental \\
\hline Progesterone, $\mathrm{kg} / \mathrm{m}^{3} \times 10^{-6}$ & $0.43 \pm 0.03$ & $0.49 \pm 0.03$ \\
\hline Estradiol-17 $\beta, \mathrm{kg} / \mathrm{m}^{3} \times 10^{-9}$ & $90.33 \pm 4.12$ & $95.67 \pm 5.68$ \\
\hline Carotene, $\mathrm{mol} / \mathrm{m}^{3}$ & $13.33 \pm 0.88$ & $2.7 \pm 0.11$ \\
\hline Cholesterol, $\mathrm{mol} / \mathrm{m}^{3}$ & $2.73 \pm 0.07$ & $0.35 \pm 0.006$ \\
\hline Ascorbic acid, $\mathrm{kg} / \mathrm{m}^{3} \times 10^{-2}$ & $0.35 \pm 0.02$ & 1.45 \\
\hline
\end{tabular}

Note: * - statistically significant difference level of the studied samples of blood serum of cows of experimental compared with the control group of cows: * $-\mathrm{P}<0.05$, ** $-\mathrm{P}<0.01, * * *-\mathrm{P}<0.001$.

\section{Indicators blood of cows in the treatment of ovarian follicular cysts on the $3^{\text {rd }}$ day after treatment $(M \pm m ; n=5)$}

\begin{tabular}{|l|c|c|}
\hline \multirow{2}{*}{ Indicator } & \multicolumn{2}{c|}{ Cows groups } \\
\cline { 2 - 3 } & Control & Experimental \\
\hline Progesterone, $\mathrm{kg} / \mathrm{m}^{3} \times 10^{-6}$ & $0.67 \pm 0.03$ & $0.87 \pm 0.03^{* *}$ \\
\hline Estradiol- $17 \beta, \mathrm{kg} / \mathrm{m}^{3} \times 10^{-9}$ & $34.67 \pm 2.76$ & $32.33 \pm 2.18$ \\
\hline Carotene, $\mathrm{mol} / \mathrm{m}^{3}$ & $16.0 \pm 1.15$ & $15.67 \pm 0.88$ \\
\hline Cholesterol, $\mathrm{mol} / \mathrm{m}^{3}$ & $2.9 \pm 0.06$ & $3.07 \pm 0.09$ \\
\hline Ascorbic acid, $\mathrm{kg} / \mathrm{m}^{3} \times 10^{-2}$ & $0.35 \pm 0.01$ & $0.37 \pm 0.009$ \\
\hline
\end{tabular}

Indicators blood of cows in the treatment of ovarian follicular cysts on the $7^{\text {th }}$ day after treatment $(M \pm m ; n=5)$

\begin{tabular}{|l|c|c|}
\hline \multicolumn{1}{|c|}{ Indicator } & \multicolumn{2}{c|}{ Cows groups } \\
\cline { 2 - 3 } & Control & Experimental \\
\hline Progesterone, $\mathrm{kg} / \mathrm{m}^{3} \times 10^{-6}$ & $1.07 \pm 0.09$ & $20.63 \pm 0.09^{*}$ \\
\hline Estradiol-17 $\mathrm{kg} \mathrm{kg} / \mathrm{m}^{3} \times 10^{-9}$ & $21.3 \pm 1.76$ & $17.0 \pm 1.0$ \\
\hline Carotene, $\mathrm{mol} / \mathrm{m}^{3}$ & $18.0 \pm 1.15$ & $3.37 \pm 0.09^{*}$ \\
\hline Cholesterol, $\mathrm{mol} / \mathrm{m}^{3}$ & $3.1 \pm 0.06$ & $0.44 \pm 0.03$ \\
\hline Ascorbic acid, $\mathrm{kg} / \mathrm{m}^{3} \times 10^{-2}$ & $0.42 \pm 0.03$ & \\
\hline
\end{tabular}

the control group and this difference was significant $(\mathrm{P}<0.01)$. This may be a sign of a more effective treatment of this disease in cows in the experimental group. The level of estradiol decreased compared to its value before the treatment, which may also be a sign of resumption of ovarian in result of treatment, but the difference between the control and experimental groups was not significant.

Carotene content did not differ significantly between the groups that may be evidence of the lack of influence of the method of treatment of this disease on its level in serum, but it increased compared to the this value before the treatment in experimental groups, which may be an indicator of the relationship of carotene metabolism in the organism and activity of the work level of reproductive system. Cholesterol level was investigated in cows within the physiological norm but in the experimental group it was higher at $5.86 \%$, which may be associated with higher levels in the serum progesterone levels of these cows, on the synthesis of what cholesterol may be used. Also its level increased during the course of treatment, which may indicate the effects of two treatments on cholesterol metabolism in the body. The level of ascorbic acid in the blood serum of cows in two groups was within the physiological norm, and little different among themselves and compared with the value before treatment.

In the analysis presented in Table 3 data show that there was an increase of progesterone 
levels in the blood serum of cows of control and experimental groups on the $7^{\text {th }}$ day after treatment compared to these indicators to treatment and the on the $3^{\text {rd }}$ day after treatment in two groups. In the cows in experimental group it was at $33.64 \%$ higher than in animals of the control group and the difference was significant $(\mathrm{P}<0.01)$. This may be indicative of continuing activation of the ovary as a result of treatment and more effective method treatment in the experimental group. The level of estradiol continued to decline in the two groups of cows compared with its value before treatment and on the $3^{\text {rd }}$ day after treatment, which may also be a sign of ovarian recovery following treatment. The values in the different groups were different within $2.96 \%$, which may be a sign of stabilization of this indicator. Carotene content between different groups was within $5.56 \%$ and the difference was not certain that may be evidence of the lack of influence of the method of treatment of this disease on its level in serum, but increased compared to that size before treatment and on the $3^{\text {rd }}$ day after treatment in the two research groups, which may indicate the relationship carotene metabolism in the body and activity level work of the reproductive system.

Cholesterol level in blood serum of cows of control and experimental groups was within the physiological norm, but in the experimental group it was higher by $8.71 \%$ and the difference was statistically significant $(\mathrm{P}<0.05)$, which may be related to increased levels in serum of cows of these groups progesterone levels, in the synthesis what of cholesterol may be used and may indicate the impact of the two treatments on the activation of the reproductive system and metabolism of cholesterol in the body simultaneously. The level of ascorbic acid in the blood serum of cows of two groups on the $7^{\text {th }}$ day after beginning treatment was within the physiological norm, but increased compared to this value before treatment and on the $3^{\text {rd }}$ day of after beginning treatment which may indicate the activation of ascorbic acid metabolism in the body of cows in the revitalization work of the reproductive system. The difference between the control and experimental group in the value of the indicator was small which may indicate a lack of differences in the method of treatment for exposure to the exchange of the compound in the body of cows. From month to two after treatment all cows showed estrus and were inseminated. Re-estrus cows were not showing and after three months they all were established as pregnant.

\section{Conclusions}

1. After treating cows with follicular cysts, on the $7^{\text {th }}$ day after treatment there was an increase of progesterone levels in the blood serum of cows control and experimental groups compared to these parameters before treatment and on the $3^{\text {rd }}$ day after treatment in two groups. This level in the experimental group was by $33.64 \%$ higher than in the animals in the control group $(\mathrm{P}<0.01)$. This may be an indicator of continuing activation of the ovary as a result of more effective treatment in the experimental group with application intramuscular liposomal emulsion phytosubstances with the addition of gonadotropin releasing hormone.

2. The level of cholesterol on the $7^{\text {th }}$ day after treatment of cows with follicular cysts in the blood serum in cows control and experimental groups was within the physiological norm, but in the experimental group it was higher by $8.71 \%(\mathrm{P}<0.05)$, which may indicate greater influence experimental regimen for the activation of the reproductive system and metabolism of cholesterol in the body.

Perspectives for further research. Due to received results, it is important to continue the research of the different schemes of treatment of follicular cysts in cows' ovary using synthetic, animal and herbal drugs and their combinations. For better understanding the processes in cows with follicular cysts of ovary and during treatment of this pathology the scientific interest is the researching of metabolic profile of blood in diseased cows in dynamics of treatment.

1. Garverick H. A. Ovarian follicular cysts in dairy cows. J. Dairy Sci., 1997, vol. 80 (5), pp. 995-1004.

2. Silvia W. J., Hatler T. B., Nuqent A. M., Laranja da Fonseca L. F. Ovarial follicular cysts in dairy cows: an abnormality in folliculogenesis. Domestic Animal Endocrinol., 2002, vol. 23, no. 1-2, pp. 167-177. 
3. Honcharov V. P. Phytotherapy in the ovarian hypofunction. Veterinary consultant, 2007, no 21-22, pp. 22-24. (in Russian)

4. Luo R., Gu X. Treating infertile milk cows by traditional Chinese medicine. Journal of Agricultural Science, 2009, vol. 1, no. 1, pp. 82-85.

5. Zanewskij A. W., Kuznecow N. A. The effectiveness of various schemes hormone therapy functional disorders of ovaries in cows. Effective stockbreeding, 2007, no. 2 (18), pp. 48-50. (in Russian)

6. Kurtiak B. M. Prevention and treatment of in- fertility cows fat-soluble vitamins. Veterinary Medicine of Ukraine, 2001, no. 3,pp. 22-23. (in Ukrainian) 7. Mindzasow K. I., Muhametova V. D., Aubakirova A. K. Biochemically screening blood cows with abuser productive function. Agriculture, forestry and water industry, March 2013, no 3. Available at: http://agro.snauka.ru/2013/03/935.

8. Vlizlo V. V., Fedoruk R. S., Ratych I. B. and other. Laboratory methods of investigation in biology, stock-breeding and veterinary. Reference book. Lviv, SpolomPubl., 2012. 764 p. (in Ukrainian) 